9. Kozhemyakin, Yu. M. Naukovo-praktichni rekomendatsiyi z utrimannya laboratornih tvarin ta roboti z nimi [Text] / Yu. M. Kozhemyakin, O. S. Hromov, N. E. Boldireva, N. V. Dobrelya, G. A. Sayfetdinova. - Kyiv: Interservis, 2017. - 156 p.

10. Protokol diagnostiki, profilaktiki i likuvannya gostrogo poshkodzhennya nirok (GPN) [Text]. - Ukrayinskiy zhurnal nefrologiyi ta dializu. - 2010. - Vol. 3. - P. 22-36.

11. Sokolovskiy, V. V. Gistohimicheskie issledovaniya v toksikologii [Text] / V. V. Sokolovskiy. - Leningrad: Meditsina, 1971. $-176 \mathrm{p}$.

12. Lapach, S. N. Statisticheskie metodyi v mediko-biologicheskih issledovaniyah s ispolzovaniem EXEL [Text] / S. N. Lapach, A. V. Chubenko, P. N. Babich. - Kyiv: MORION, 2001. - 408 p.

13. Strukov, A. I. Patologicheskaya anatomiya [Text] / A. I. Strukov, V. V. Serov. - Moscow: GEOTAR-Media, 2015. - 878 p.

Дата надходження рукопису 15.08.2017

Anna Markina, Senior Assistant, Department of Clinical Pharmacology, Institute of Pharmacy Professionals Qualification Improvement National University of Pharmacy, Zakhysnykiv Ukrainy sq., 17, Kharkiv, Ukraine, 61001

E-mail: Kolomanya7@gmail.com

Oksana Mishchenko, Doctor of Pharmaceutical Sciences, Professor, Head of Department, Department of Clinical Pharmacology, Institute of Pharmacy Professionals Qualification Improvement National University of Pharmacy, Zakhysnykiv Ukrainy sq., 17, Kharkiv, Ukraine, 61001

E-mail: clinpharmacol_ipksph@nuph.edu.ua

Julia Laryanovska, PhD, Senior Researcher, Central research laboratory, National University of Pharmacy, Pushkinska str., 53, Kharkiv, Ukraine, 61002

E-mail: cndl@nuph.edu.ua

UDC 615.322:633.13-035.261:616.379-008.64:57.084

DOI: 10.15587/2519-4852.2017.113503

\title{
NEW POSSIBILITIES OF USE OF OAT RAW MATERIALS FOR INVESTIGATION OF BIOLOGICALLY ACTIVE COMPONENTS IN THERAPY OF EXPERIMENTAL DIABETES
}

\author{
(C) L. Gayova, N. Yurzhenko, O. Mysnik
}

Метою роботи було запропонувати технологію аква динамічного екстрагування біологічно активних
речовин із соломи вівса. Встановлено, ще кількість екстракту та концентрація екстрагованих речовин
залежать від тривалості процесу екстракиії. Склад досліджуваного фітокомплексу доводився ядерно-
магнітним резонансом. Склад вищих жирних кислот фітокомплексу екстракту вівсяної соломи вивчали
иляхом газової хроматографії. Показана можливість використання фітокомплексу з екстракту соломи
вівса в дослідженні метаболізму ліпідів міокарду в експериментальних тварин з моделлю иукрового діа-
бету. Методи дослідження: оптимізували процес водного вилучення екстракту соломи вівса за допомогою динамічного характеру та підвищених температур, щзо може бути кращим очевидним недолікам, запропонованим раніше. Для того, щуоб оцінити відмінності в вмісті сумішей речовин, отриманих з первинного екстракту, було відзначено спостереження спектрів $H^{l}$-ЯМР в $D_{2} O$. Проведено газовохроматографічний аналіз спектру жирних кислот у досліджуваному фітокомплексі та ліпідів білих кров'яних клітин міокарда. Моделювання иукрового діабету проводилося иляхом внутрішньоклітинного введення стрептозотоцину в дозі 55 мг на кілограм маси тіла щурів протягом 6 тижнів.

Результати: був розроблений більш економічно доиільний підхід до одержання фітокомплексу шляхом екстрагування соломи вівса з повним збереженням біологічно активних речовин. Жирно-кислотний склад фітокомплексу екстракту вівсяної соломи вивчався газовою хроматографією. Розглянуто склад фітокомплексу екстракту соломи вівса за допомогою ядерно-магнітного резонансу

Висновки: Показано можливість використання фітокомплексу з екстракту вівсяної соломи в дослідженні метаболізму ліпідів міокарда в експериментальних тварин з моделлю иукрового діабету

Ключові слова: Avena Sativa, солома, екстракція, поліфеноли, антиоксиданти, жирні кислоти, експериментальний діабет

\section{Introduction}

The study of natural phytocomplexes permitted to distinguish a wide group of biologically active substances of polyphenolic nature, in particular, flavonoids. At the moment, a considerable number of scien- tifically-practical researches aimed at studying polyphenol component of numerous products of economic activity, such as wine [1], some agricultural products $[2,3]$, and herbs, among which lists the oat, Avena Sativa, in its various natural and synthetic forms, are 
known. Polyphenols of the vegetative nature are represented by a variety of forms that potentially anticipates a wide range of non-specific and specific biological activity, and actualizes its further research and application in the medical practice $[4,5]$.

\section{Formulation of the problem in a general} way, the relevance of the theme and its connection with important scientific and practical issues

The proposed extraction technologies of substances do not have harmful waste but include the formation of significant side products, bran of oat straw on the stage of substrate preparation, and the waste substrate after the extraction. As we can see from the previous discussion, the proposed technology of extraction requires modern economically justifiable modernization.

Therefore, our task was to improve the technology of extraction of biologically active substances.

Fatty acid composition of the phytocomplex of the oat straw extract will be studied by gas chromatography. Composition of the phytocomplex of the oat straw extract will be studied by nuclear magnetic resonance.

The possibility of using a phytocomplex from an oat straw extract in the study of the metabolism of myocardium lipids in experimental animals with a model of diabetes will be indicated.

3. Analysis of recent studies and publications in which a solution of the problem are described and to which the author refers

An outstanding discovery of the existence of the C$\mathrm{P}$-vitamin complex was a driving impulse for the development of studying flavonoids in plants. The realization of its immense role in metabolic processes and impacts on wide range of physiological effects initiated the developing of medicines where polyphenols and ascorbic acid are a part of a native composition (for example, medicinal product Kalifen consisting of viburnum extract [6]), or medicinal products, where substances of flavonoid-contained extracts are used as synthetic ascorbate modifiers. The typical example of the ones is a ramified sample of dosage forms, similar to the medicinal product Ascorutin.

An ascertainment of the fact that polyphenolic substances form complexes with the ascorbic acid, resulting in an apparent effect of the synergism of anti-oxidant action substances was a significant discovery in the pharmaceutical application of these polyphenols. The ascorbic-gallic medicinal product was suggested as the dosage form that allows implementing the possibilities in the medical practice. The Gallic acid (3,4,5-trihydroxybenzoic acid) is one of the simplest commercially-accessible forms of polyphenols (CAS\#149-91-7), that composes many vegetable based extracts. The realisation of this fact allowed not only to create relatively simple and adequate model systems to study chemical and physicochemical nature of ascorbateflavonoid interaction in vitro but also to approve physiological characteristics of medicinal products in vivo on the level of initial clinical trials [7].

Soon, the idea evolved in the practical-pharmaceutical area. The gallic component of a medicine was replaced with the tannin, resulting in the levelling of numerous production problems related to the standardisation of raw materials and final products. Medical tannin is a synthetic substance (tannin CAS\#1401-55-4; food additive E-181). The medicine composed of tannin and ascorbic acid is called Galascorbinum [8].

At the same time, appeared examples of the medical application of the medicine to treat mammalogical microtraumas [8] of lying-in women, or as a contraceptive [9]. The remedy, in its variations, was used in clinical practice, particularly in a complex with the medicine Asparcam to treat heart conditions [10]. However, the main direction of the medicine application is prevention and treatment of physiological defects directly connected with the disorder of oxidoreduction process in cells' mitochondria, as a result of considerable radioactive irradiation. It caused an active application of the medicine in oncologic chemotherapy practice, and in a military area $[11,12]$.

The work [12] reflects further tendencies in the medical application of C-P-vitamin complex, namely the replacement of medical tannin with the products of extraction from plant raw materials, in particular, the husk of oat seed that of technical-economic reasons appeared to be a suitable variant of native raw material use.

A comparative analysis of the efficacy of the preventive and therapeutic action of Galascorbinum and investigated phytocomplex [12] in addition to numerous local observations, allowed making several conclusions. Both products in different cases of its application do not manifest toxical effects, thus providing opportunities for further expansion of the assortment and the field of application of polyphenol-containing compounds. It allows us to assume that the effect is determined not only by the ascorbate-polyphenolic composition but also by a complex of substances inherent to oat raw materials. For example, according to research results [13], oat straw aqueous extract contains 36 identified components of polyphenolic, polysaccharides, lipids, and aminoacid nature that predetermine certain therapeutic effects [14].

Compared with other plant products substance contains the group of non-flavonoid polyphenols (about 20 functional derivatives of cinnamic acid) [15] which is called avenanthramides, unsaturated amide compounds with polyphenolic functions (Fig. 1), which are characterized by unique manifestations of antioxidant action [14].

The polyphenolic nature of the compounds predetermines antioxidant properties and the presence of carboxylic and ethenic fragments gives the substances antioxidant properties, usually inherent to unsaturated fatty acids. The peptide group allows for compounds to take part in metabolic transformations inherent to amino acids and proteins.

The patent [15] suggests the production and medical use of phytocomplexes, where the source of polyphenols is oat raw materials in its variations, grain, straw, milk stage plants. Also was suggested the technology of industrial production of oat extracts with the potential of the use of various substances [15]. The content of extracted substances in tinctures estimates at the level of $0,8 \%$ on condition that the extraction is conducted with $38 \%$ aqueous solution of ethanol. Basically, the technology involves a concentration of solutions to the content of substances at the level of 5-30\%, or even powdered medicine by means of rotary-dispersing vacuum drying of primary extracts, although being aimed mainly at obtaining aqueous-alcoholic tinctures. 


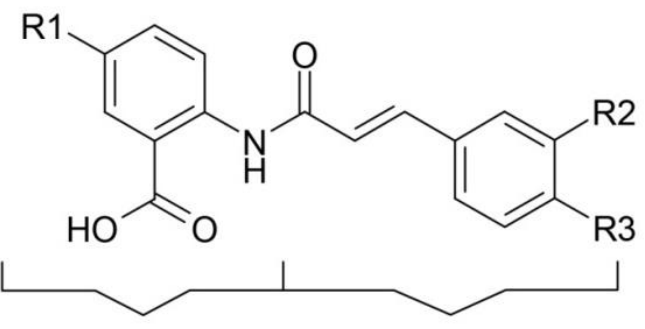

\begin{tabular}{|l|c|c|c|}
\hline \multirow{2}{*}{$\begin{array}{l}\text { Fragment } \\
\text { 5-hidroxyanthranilic acid }\end{array}$} & Fragment & $\mathrm{R} 2$ & $\mathrm{R} 3$ \\
\cline { 2 - 4 }$(\mathrm{R} 1=\mathrm{OH})$ & $\mathrm{A}-\mathrm{p}$-coumaric & $\mathrm{H}$ & $\mathrm{OH}$ \\
\cline { 2 - 4 } & $\mathrm{B}$ - ferrulic & $\mathrm{OMe}$ & $\mathrm{OH}$ \\
\cline { 2 - 4 } & C-caffeic acid & $\mathrm{OH}$ & $\mathrm{OH}$ \\
\hline
\end{tabular}

Fig. 1. General structure of avenanthramides AVA-A, AVA-B, AVA-C

The next technological process [16] has no significant differences from the previous [17], except for the primary use of oat plants of milky-wax ripeness instead of milk ripeness. However, the patent [16] contains conclusions.

\section{The field of research considering the general problem, which is described in the article}

The proposed technologies do not have harmful waste but include the formation of significant side products, bran of oat straw on the stage of substrate preparation, and the waste substrate after the extraction. As we can see from the previous discussion, the proposed technology of extraction requires modern economically justifiable modernization.

\section{Formulation of goals (tasks) of article}

Firstly, on the basis of clinical trials, the medicine was defined as non-toxic in all the forms and classified as a general one. Secondly, it was stated the difference in the colour of extracts that affirms a certain lability of its content but is not considered as a critical restriction for production and consuming of the medicine. Finally, after the sedimentation, the extract is filtered, indicating the presence of nonsoluble particles which may appear as a result of physical contamination by the aggregates of the substrate, or coagulation of certain extracted substances.

Therefore, our task was to improve the technology of extraction of biologically active substances.

Fatty acid composition of the phytocomplex of the oat straw extract will be studied by gas chromatography. Composition of the phytocomplex of the oat straw extract will be studied by nuclear magnetic resonance.

The possibility of using a phytocomplex from an oat straw extract in the study of the metabolism of myocardium lipids in experimental animals with a model of diabetes mellitus will be indicated.

6. Presentation of the main research material (methods and objects) with the justification of the results

Experimental. Laboratory researches mentioned below is an attempt to optimise the process of aqueous extraction of the oat straw that in prospect, with the help of dynamic character and increased temperatures, can prevail obvious disadvantages of technology offered before $[15,17]$.

Extraction and sample preparation. The bulk weight of dry chopped oat straw in these researches is $(0,12 \pm 0,01) \mathrm{g} / \mathrm{sm}^{3}$ on condition that the length of the used aggregates is $5 \mathrm{~mm}$ and aggregates are made by chopping the native raw materials on disagglomerator of rotary-cutting type. The calculation of the bulk weight was held in compliance with standard methods. The results are basic but can vary from given ones because of individual qualities of substrates, in particular, fluctuation of humidity and thickness of natural aggregates.

The extraction was held in the following way. The substrate $(100 \pm 1) \mathrm{g}$ was loaded into a thermoresistant cup (volume -21 ) with huge teflon armature for the powerful magnetic type mixing machine. Measured out $(1000 \pm 10) \mathrm{ml}$ of distilled water and transferred into the glass by portions, trying to ensure maximum contact of the substrate with it. Placed the glass with the mixture in the mixer and turned on heating and stirring mode. Thermal insulation and relative sealing capacity during the extraction was provided using aluminium foil. The beginning of the process was fixed visually by the formation of the gas phase and by the temperature reaching $100 \pm 5^{\circ} \mathrm{C}$.

At the end of the extraction time, the reaction mixture was filtered using Schott coarse fritted filter or Büchner funnel with filter paper, and carefully pressed under discharging using a water jet pump. The pressing and the filtration were completed when the filtrate collection rate did not exceed 1 drop in 5 minutes. In practice, the expected result was achieved for $8-10$ hours. It is recommended to keep the mass on the filter over the night, and then squeeze it under the vacuum for 1 hour to collect an additional amount of the filtrate, which usually does not exceed $50 \mathrm{ml}$ and is taken in calculations as a magnitude of the deviation of the measurements.

The volume of the received filtrate was measured and determined the content of solid residues at least in two parallel samples. For this purpose, 50-70 $\mathrm{g}$ of the extract was transferred to the evaporation cup and held in a drying chamber at $100-110{ }^{\circ} \mathrm{C}$ until the constant mass was ob- 
tained when the results of 3 successive measurements do not differ by more than $0,01 \mathrm{~g}$ for 1 hour.

Gained dry substance of the extracts after the granulation looks like dark-brown homogeneous dust. The extracted compounds have relatively low solubility in water, which appears as a result of caramelization of carbohydrates, and tend to fall out if to concentrate or cool the initial solution. Probably, the nature of the substances that fall out into solids and remain in the solution is similar. For the purpose of preservation of target substances, it was carried out a further modification with ascorbic acid on the basis of the primary extract. The results of the dynamic extraction of the oat substrate at elevated temperatures are given in Table 1.

Table 1

Quantitative indicators of extraction process of oat straw substrate

\begin{tabular}{|c|c|c|c|c|}
\hline \multirow{2}{*}{ Extraction period, $\mathrm{h}$} & \multicolumn{2}{|c|}{ Quantity of extract, $\mathrm{ml}$} & \multicolumn{2}{|c|}{ Solid residues, $\%$} \\
\hline & by experiments & average & by experiments & average \\
\hline \multirow{2}{*}{1} & $570 \pm 30$ & \multirow{2}{*}{$580 \pm 40$} & $1.69 \pm 0.01$ & \multirow{2}{*}{$1.59 \pm 0.12$} \\
\hline & $590 \pm 30$ & & $1.49 \pm 0.01$ & \\
\hline \multirow{2}{*}{2} & $640 \pm 30$ & \multirow{2}{*}{$620 \pm 80$} & $1.47 \pm 0.02$ & \multirow{2}{*}{$1.53 \pm 0.08$} \\
\hline & $570 \pm 30$ & & $1.59 \pm 0.01$ & \\
\hline \multirow{2}{*}{3} & $380 \pm 30$ & \multirow{2}{*}{$380 \pm 30$} & $1.63 \pm 0.04$ & \multirow{2}{*}{$1.78 \pm 0.19$} \\
\hline & $380 \pm 30$ & & $1.92 \pm 0.05$ & \\
\hline \multirow{2}{*}{4} & $410 \pm 30$ & \multirow{2}{*}{$420 \pm 40$} & $1.54 \pm 0.01$ & \multirow{2}{*}{$1.08 \pm 0.4 \mathrm{C}$} \\
\hline & $430 \pm 30$ & & $0.61 \pm 0.02$ & \\
\hline 5 & $130 \pm 30$ & $130 \pm 30$ & $1.92 \pm 0.05$ & $0.51 \pm 0.01$ \\
\hline
\end{tabular}

According to the results of the laboratory studies (Table 1), it can be concluded that the amount of the obtained extract depends on the duration of the process. If in 1-2 hours the amount of the extract within the margins of error does not change, then further increase of the extraction time up to 3 hours causes a rapid decrease in quantity. In 3-4 hours the amount of the extract within the margins of error remains the same. However, the amount of the extract in the sample for 5 hours is much smaller compared with the previous ones. Obviously, prolonged heating causes substantial swelling of the substrate, which is a natural barrier to the extraction of the liquid phase from the reaction mixture. Thus, it is reasonable to carry out the extraction during 1-2 hours.

Another determining criterion of the process efficiency is the dependence of the obtained solutions' concentration from the duration of the extraction (Table 1). The character of this dependence is similar to the previous one. The content of the extracted substances in samples with the duration of the process for 1-4 hours is within the measurement accuracy. However, it should be noted that in the 4-hours sample there is a significant range of values of the content of the extracted substances. It indicates the instability of the process and considerable dependence of the results from random factors. A 5-hours sample is characterised by a further decrease in the concentration of the extract to technologically inap- propriate parameters, which may result in the manifestation of sorption properties of the transformed substrate, and its irreversible effect may result in the caramelization of carbohydrates. This observation, on principle, is conformed to scattered data on the extract output in 4-hours sample.

Thus, an increase in the duration of the process above 4 hours seems inappropriate not only for energy conservation reasons. Apparently, the swelling of the substrate occurs with a change of its properties and results both in a decrease of the extract quantity and in the concentration of the extracted substances. Estimated data of the efficiency of the process is presented in Table 2, relating the mass of the extracted substances per 11 of the extract and $1 \mathrm{~kg}$ of the substrate (confidential interval, $95.0 \%$ ).

The comparison of the results of filtration of the primary extract and its centrifugation (5000 r/min) did not reveal any significant differences. Visually, a number of solids received as a result of centrifugation of the primary extracts are insignificant, which conforms to the analytical data for the determination of solid residue (Table 3). The values of the content of the extracted substances in the centrifugates within the measurement accuracy coincide with the initials. The samples of centrifugates have an expressed Tyndall effect that affirms the colloidal nature. 
Estimation of effectiveness of process of oat straw extraction

\begin{tabular}{|c|c|c|c|c|}
\hline \multirow{3}{*}{ Extraction period, $\mathrm{h}$} & \multicolumn{4}{|c|}{ Quantity of extracted substance } \\
\hline & \multicolumn{2}{|c|}{ per 11 of extract, $g / 1$} & \multicolumn{2}{|c|}{ per $1 \mathrm{~kg}$ of substrate, $\mathrm{g} / \mathrm{kg}$} \\
\hline & by samples & average & by samples & average \\
\hline \multirow{4}{*}{1} & 16.8 & \multirow{4}{*}{$15.9 \pm 1.2$} & 90.72 & \multirow{4}{*}{$93.7 \pm 8.5$} \\
\hline & 17.0 & & 100.30 & \\
\hline & 14.8 & & 82.88 & \\
\hline & 15.0 & & 100.74 & \\
\hline \multirow{6}{*}{2} & 14.9 & \multirow{6}{*}{$15.1 \pm 0.6$} & 95.36 & \multirow{6}{*}{$95.1 \pm 6.2$} \\
\hline & 14.9 & & 102.81 & \\
\hline & 14.5 & & 92.80 & \\
\hline & 14.6 & & 100.74 & \\
\hline & 15.8 & & 85.32 & \\
\hline & 15.9 & & 93.81 & \\
\hline \multirow{4}{*}{3} & 15.9 & \multirow{4}{*}{$17.8 \pm 1.8$} & 55.65 & \multirow{4}{*}{$66.7 \pm 9.5$} \\
\hline & 16.7 & & 66.80 & \\
\hline & 18.7 & & 65.45 & \\
\hline & 19.7 & & 78.80 & \\
\hline \multirow{4}{*}{4} & 15.3 & \multirow{4}{*}{$10.7 \pm 5.3$} & 58.14 & \multirow{4}{*}{$44.1 \pm 21.3$} \\
\hline & 15.4 & & 66.22 & \\
\hline & 5.9 & & 23.60 & \\
\hline & 6.3 & & 28.35 & \\
\hline \multirow{2}{*}{5} & 5.0 & \multirow{2}{*}{$5.1 \pm 0.1$} & 5.00 & \multirow{2}{*}{$6.3 \pm 1.9$} \\
\hline & 5.1 & & 7.65 & \\
\hline
\end{tabular}

Table 3

Solid residue of initial extracts and its centrifugates

\begin{tabular}{|c|c|c|}
\hline Extraction period, $\mathrm{h}$ & $\begin{array}{c}\text { Average value of solid residue con- } \\
\text { tent in extract after centrifugation, } \%\end{array}$ & $\begin{array}{c}\text { Average value of solid residue } \\
\text { content in initial extract, } \%\end{array}$ \\
\hline 1 & $1.55 \pm 0.01$ & $1.59 \pm 0.12$ \\
\hline 4 & $0.58 \pm 0.01$ & $0.61 \pm 0.02$ \\
\hline
\end{tabular}

$\mathbf{H}^{\mathbf{1}}$-NMR spectrometry analysis. In order to evaluate the differences in the content of the mixtures of the substances, received from the primary extract and centrifugate, was additionally noted observation of $\mathrm{H}^{1}-$ NMR spectra in $\mathrm{D}_{2} \mathrm{O}$ (Varian Gemini $400 \mathrm{MHz}$ spectrometer). The analysis is limited to a qualitative comparison of the nature of the spectra. The following considerations refer only to the components of the extract that are enough soluble in aqueous media.

In general, the spectra contain the same group of signals, $\delta$, ppm (relative integral intensity of the signal): $1,1-1,5(3,73)-1,1-1,5(6,21) ; 1.92$ (accepted for 1.0) $1.95(1) ; 2.13(0.81)-2.13$ (1.33); 3.26-4.33 (9.15) 3.23-4.26 (9.71), respectively. The obtained data testify about close affinity of the qualitative composition of the water-soluble compounds mixture contained in the primary extract of oat straw and its centrifugate.

The integral intensity of the specified group of signals in both samples is comparable. A separate exception is a group of the strongest field signals at $\delta$, ppm 1.1-1.5, where the differences in intensities (3.73 and 6.21 respectively) of peaks lie beyond the limits of possible error. It can be assumed that this is a result of differences in solubility of compounds in the aqueous media. Obviously, this group of signals should be ascribed to a number of substances having higher solubility in water. Probably, these signals can be ascribed to methyl groups in structures that do not have proton neighbours, most likely to substituents at the aromatic fragment of molecules or to compounds of the hydrocarbon structure.

Weak field signals approximately 5,25 ppm are inconsiderable which indicates a few aromatic protons. This may appear as a result of the low solubility of the corresponding compounds in water (artifacts of the spectrum registration in the heterogeneous system, in particular) or, taking into account the collisions with the integral signal intensities $\delta$, ppm 1.1-1.5, a significant degree of functionalization of phenyl fragments - minimising the contribution of aromatic compounds to the total number of protons of aliphatic nature predominantly.

The signals at $\delta$, ppm 4.75-5.25 are due to residual protons of water introduced into the system with the test substance and solvent. The widespread nature of the signal of water protons undeniably indicates the course of the processes of exchange, i. e. the presence of hydroxyl groups of phenolic or alcoholic nature. The high intensity of this signal indicates the high content of water in a visually dry sample of a substance, i. e. its inclination to solvation. This is the evidence of the presence of a significant number of polar fragments in the structures of the extracted substances, in particular with $\mathrm{C}-\mathrm{O}$ bonds (hydroxyl, carbonyl, and carboxyl groups), that fully coordinates with the observation on the extension of the NMR signal.

It can be assumed that a complex group of multiplets at $3.23-4.33 \mathrm{ppm}$ is due to the protons of carbohy- 
drate nature which can be potential exchange donors of protons because of substantial content of hydroxyl groups.

The spectra characteristics of the organic soluble components of the solid residue of the extract insignificantly differ from the water soluble. The substance is not completely dissolved in DMSO-d6, which complicates the fixation of the spectrum. The spectrum does not contradict previous conclusions about the presence of aliphatic fragments in the compounds and intensive proton exchange processes. $8.76 \mathrm{ppm}$ signals confirm the presence of aromatic fragments in substances. $11.27 \mathrm{ppm}$ signal can be interpreted as an evidence of the presence of carboxyl group in the extracted substances.

Analysis of the content of higher fatty acids. Gas chromatographic analysis of the spectrum of fatty acids in the studied phytocomplex and in the lipids of the white blood cells of the myocardium was performed on a gas chromatograph of the Cvet-500 series in isothermal mode from a flame-ionization detector. Quantitative evaluation of the spectrum of fatty acids was carried out by the method of normalizing the planes and determined the proportion of acids in the percentage.

During studying fatty acid composition of lipids in the myocardium of experimental animals of the investigated phytocomplex, lipid extraction was carried out according to the known Folche method, and the hydrolysis and methylation of higher fatty acids of lipids were carried out using the method of Sinyak K. M. and co-authors [18].

Modeling of diabetes. Experiments were conducted on white rats of both sexes weighing 180-250 g, which were held in vivarium. Modeling of diabetes was performed by intraperitoneal streptozotocin injection at dose of $55 \mathrm{mg}$ per kilo of body weight of rats for 6 weeks [18].

The animals were decapitated under chlorideurethane anesthesia. The level of glucose was determined in blood serum of experimental animals (Table 4).
Results Table 4 indicate a significant increase of glucose in the blood serum of white rats in modeling diabetes within six weeks of observation.

Table 4

Blood glucose content in serum. $(\mathrm{M} \pm \mathrm{m}, \mathrm{n}=7)$

\begin{tabular}{|c|c|c|}
\hline \multirow{2}{*}{ Group of animals } & \multicolumn{2}{|c|}{ Glucose, mmol/l } \\
\cline { 2 - 3 } & Initial & After 6th week \\
\hline Intact rats & $4,25 \pm 0,52$ & $4,31 \pm 0,47$ \\
\hline Diabetes Modeling & $4,37 \pm 0,40 *$ & $22,10 \pm 1,72 *$ \\
\hline
\end{tabular}

Note: $*-p<0.05-$ statistical significance relative to control

\section{Findings from the research and prospects of further development of this area}

Fatty acid lipid spectra of the studied phytocomplex and myocardium of rats. Lipid bilayer is an essential element of cell membranes and its condition significantly affects the functioning of many cellular components, including membrane proteins and enzymes. In recent years, it has been found that phospholipids incorporated in cell membranes can act as ion channels, regulate the activity of membrane binding enzymes and passive ion transport, modify the adhesive and immune properties of cells. A characteristic feature of the molecular organization of biomembranes is the asymmetry of its phosphofilipid composition - on the outer side of the cell localized phosphatidylcholine, on the inner - phosphatidylethanolamine and phosphatidy-lserine.

At the same time, polyunsaturated fatty acids in the processes of free radical oxidation are substrates of lipid peroxide oxidation. Palmitic acid is involved in the regulation of hormones, directly contributes to such an important process as activation of the synthesis of elastin, collagen, hyaluronic acid and glycosaminoglycans. Thus, it exerts a stimulating effect on the renewal and regeneration of the dermis (intercellular substance) [19].

Consider the results of the gas chromatographic analysis of the studied phytocomplex and heart of the rats under conditions of diabetes, that are shown in Table 5.

Table 5

The content of fatty acids $(\%)$ in the heart of rats $(\mathrm{M} \pm \mathrm{m})$ and the phytocomplex under study $(\%)$

\begin{tabular}{|c|c|c|c|c|}
\hline Higher fatty acids & $\begin{array}{c}\text { Control group } \\
\mathrm{n}=7\end{array}$ & $\begin{array}{c}\text { Experimental } \\
\text { diabetes } \mathrm{n}=14\end{array}$ & Phytocomplex $\%$ & $\begin{array}{c}\text { Experimental diabetes }+ \\
\text { phytocomplex } \mathrm{n}=7\end{array}$ \\
\hline $\mathrm{C} 16: 0$ & $14.4 \pm 1.0$ & $10.2 \pm 1.0^{*}$ & 79.0 & $15.9 \pm 2.3^{* *}$ \\
\hline $\mathrm{C} 18: 0$ & $12.7 \pm 1.0$ & $11.1 \pm 0.8$ & 3.7 & $11.6 \pm 1.2$ \\
\hline $\mathrm{C} 18: 1$ & $11.5 \pm 0.6$ & $32.4 \pm 1.5^{*}$ & 2.5 & $18.3 \pm 2.5^{* *}$ \\
\hline $\mathrm{C} 18: 2$ & $13.6 \pm 1.0$ & $20.2 \pm 2.0$ & 12.3 & $38.1 \pm 3.2$ \\
\hline $\mathrm{C} 20: 4$ & $47.8 \pm 1.5$ & $26.1 \pm 1.7$ & 1.2 & $27.5 \pm 2.4$ \\
\hline SEFA & $27.1 \pm 1.6$ & $21.3 \pm 2.0$ & 82.7 & $72.5 \pm 3.2$ \\
\hline$\Sigma$ UEFA & $72.9 \pm 2.0$ & $78.7 \pm 1.8$ & 17.3 & $54.2 \pm 2.8^{* *}$ \\
\hline$\Sigma$ PEFA & $61.4 \pm 2.1$ & $46.6 \pm 1.8^{*}$ & 14.7 & \\
\hline
\end{tabular}

Note: $*-p<0.05$ statistical significance relative to control; $* *-p<0.05$ statistical significance between the model of diabetes and phyto correction

The data in Table 5 indicate changes in the fatty acid composition of the lipids of the heart of animals and indicate a significant decrease in the content of palmitic acid for $29 \%$, which causes a decrease in the saturation of the lipid complex of the heart on $21 \%$. At the same time there is an increase in the proportion of oleic acid in 2.8 times and linoleic acid in 1.48 times against the background of reduction of essential arachidonic acid by $45 \%$. Thus, in experimental diabetes a complex of unsaturated lipids growth of $8 \%$ and amount of polyunsaturated fatty acids by $24 \%$. In investigational phytocomplex with oat straw extract observed normalization of lipid metabolism, which prevents the trigger mechanism of inflammatory and destructive processes. 
8. Conclusions from the conducted research and prospects for further development of this field

1. There was developed more economically expedient approach to obtaining a phytocomplex by extracting oat straw with full preservation of biologically active substances.

2. Fatty acid composition of the phytocomplex of the oat straw extract was studied by gas chromatog- raphy. Composition of the phytocomplex of the oat straw extract was studied by nuclear magnetic resonance.

3. The possibility of using a phytocomplex from an oat straw extract in the study of the metabolism of myocardium lipids in experimental animals with a model of diabetes mellitus is shown.

\section{References}

1. Avar, P. Investigation of Phenolic Components of Hungarian Wines [Text] / P. Avar, M. S. P. Nikfardjam, S. KunságiMáté, G. Montskó, Z. Szabó, K. Böddi et. al. // International Journal of Molecular Sciences. - 2007. - Vol. 8, Issue 10. - P. 10281038. doi: 10.3390/i8101028

2. Kushwaha, S. C. Nutritional composition of detanninated and fresh pomergranate peel powder [Text] / S. C. Kushwaha, M. B. Bera, P. Kumar // IOSR Journal Of Environmental Science, Toxicology And Food Technology. - 2013. - Vol. 7, Issue 1. P. 38-42. doi: 10.9790/2402-0713842

3. López-Martínez, L. M. A 1H NMR Investigation of the Interaction between Phenolic Acids Found in Mango (Manguifera indica cv Ataulfo) and Papaya (Carica papaya cv Maradol) and 1,1-diphenyl-2-picrylhydrazyl (DPPH) Free Radicals [Text] / L. M. López-Martínez, H. Santacruz-Ortega, R.-E. Navarro, R. R. Sotelo-Mundo, G. A. González-Aguilar // PLOS ONE. - 2015. Vol. 10, Issue 11. - P. e0140242. doi: 10.1371/journal.pone.0140242

4. Erdem, F. Estimation of organic matter digestibility, metabolizable energy, phenolic compounds and antioxidant activity of stems and seeds of the Juncus acutus plant in ruminant nutrition [Text] / F. Erdem, N. Cetinkaya, C. Nisbet, E. Altin // South African Journal of Animal Science. - 2016. - Vol. 45, Issue 5. - P. 502. doi: 10.4314/sajas.v45i5.7

5. Shadi, T. Z. A review of four common medicinal plants used to treat eczema [Text] / T. Z. Shadi, A. Z. Talal // Journal of Medicinal Plants Research. - 2015. - Vol. 9, Issue 24. - P. 702-711. doi: 10.5897/jmpr2015.5831

6. Kushnerova, N. F. Plant complexes of polyphenols in the recovery of liver functions in patients with alcoholism [Text] / N. F. Kushnerova, S. Ye. Fomenko, V. H. Sprygin, T. V. Kushnerova, L. N. Lesnikova // Health. Medical ecology. Science. 2009. - Issue 4-5 (39-40). - P. 95-97.

7. Shamrai, Ye. F. Chemical interaction and biological interconnection of ascorbic acid and some polyphenols [Text]: abstract of Dr. Sci. (Biol.) dissertation / Ye. F. Shamrai. - Kyiv, 1952. - 19 p.

8. Pat. No. 105777. Method of preparation of the medicine Galaskorbinum [Text] / Shamrai Ye. F. - No. 2713/454356; declareted: 28.10 .1953

9. Pat. No. 130415. Contraceptive pills [Text] / Shamrai Ye. F. - No. 645652/31; declareted: 01.12.1959, Bul. No. 14.

10. Pat. No. 18108 UA. Method for treatment of chronic ischemic heart disease in elderly and old age patients. MPK: A61K 31/015, A61P 9/10, A61K 31/185 [Text] / Kraidashenko O. V., Berezin O. Ye. - declareted: 01.07.1997.

11. Shamrai, Ye. F. Recommendations for the use of galascorbinum in radiation therapy of cancer patients [Text] $/$ Ye. F. Shamrai, N. Ya. Dziubko. - Kyiv, 1968.

12. Naumova, H. M. Comparative biological activity of galascorbinum and askopol in radiolesions of the body (experimental studies) [Text]: abstract of Dr. Sci. (Med.) dissertation / H. M. Naumova. - Kyiv, 1975. -25 p.

13. Mitrofanov, R. Yu. Study of chemical composition of aqueous extract of oat straw (Avena Sativa L.) and study of its growth regulating properties [Text] / R. Yu. Mitrofanov, V. N. Zolotukhin, V. V. Budaieva // Polzunovskyi vestnik. - 2010. - Vol. 1, Issue 4. - P. 174-179.

14. Mushtaq, A. A review on Oat (Avena sativa L.) as a dual-purpose crop [Text] / A. Mushtaq, Gul-Zaffar, A. Dar, H. Mehfuza // Scientific Research and Essays. - 2014. - Vol. 9, Issue 4. - P. 52-59. doi: 10.5897/sre2014.5820

15. Pat. No. 2145864 RU. Phytocomplex for prevention and treatment of diseases of different etiology. MKP A61K35/78 [Text] / Ponomariova A. H., Medvedev V. M. - No. 98123970/14; declareted: 30.12.1998; published: 27.02.2000.

16. Pat. No. 2282459 RU. Tincture of Avena Sativa Z. of milk-wax stage of ripeness, medicine composed Avena Sativa Z. of milk-wax stage of ripeness, method of preparation of tincture of Avena Sativa Z. of milk-wax stage of ripeness. MKP A61K36/899 [Text] / Linnikova V. A., Linnikov A. M. - No. 2004123801/15; declareted: 03.08.2004; published: 27.08.2006.

17. Pat. No. 2125462S1 RU. Tincture of Avena Sativa Z. of milk stage, medicines composed of Avena Sativa Z. of milk stage and methods of its preparation. MKP A61K35/78 [Text] / Open joint-stock company Pharmaceutical factory of St. Petersburg. No. 98101233/14; declareted: 21.01.1998; published: 27.01.1999.

18. Yaremenko, O. B. Otsinka zhyrnokyslotnoho skladu lipidiv krovi u khvorykh na revmatoidnyi artryt [Text] / O. B. Yaremenko, O. Yu. Kamysh, T. S. Briuzina // Medychna khimiya. - 2005. - Issue 2. - P. 86-88.

19. Gorlova, O. S. Ekologiya i farmakologicheskiye svoystva Vakhty trekhlistnoy (menyanthes trifoliata 1.) [Text] / O. S. Gorlova // Uchenyye zapiski UO VGAVM. - 2016. - Vol. 52, Issue 3. - P. 30-32.

\section{Рекомендовано до публікащії д-р мед. наук, професор Натрус Л. В.} Дата надходження рукопису 08.08.2017

Gayova Lyudmila, MD, Professor, Department of Bioorganic and Biological Chemistry, Bogomolets National Medical University, T. Shevchenko blvd., 13, Kyiv, Ukraine, 01601

Yurzhenko Nataliya, PhD, Senior Lecturer, Department of Bioorganic and Biological Chemistry, Bogomolets National Medical University, T. Shevchenko blvd., 13, Kyiv, Ukraine, 01601

Mysnik Olga, PhD, Associate Professor, Department of Bioorganic and Biological Chemistry, Bogomolets National Medical University, T. Shevchenko blvd., 13, Kyiv, Ukraine, 01601 